mysterious forms. The answer to it is that we do not yet know enough and that we must go on working, and we look forward to the time when all systematic work will include both larva and adult, and a truly natural classification will result.

Apart from the number of biological problems which arise from the study of decapod larvæ and their systematic interest, they are of much importance economically. For the fisheries investigator a detailed knowledge of the life-histories of all those of food value is essential; for the oceanographer the study of currents is materially helped by their accurate determination. The book bristles with problems. It is indispensable to all specialists on the subject, to the general zoologist and to the student.

The illustrations, in pure outline, are exactly suitable to the subject. With the exception of one or two, they are all original and have not been published before. The form of the volume is in every way as good as usual, and the Ray Society is to be congratulated on the production of such a volume in these difficult times. The companion volume by Gurney, "A Bibliography of Decapod Larvæ", was published by the Ray Society in 1939 .

\section{THE HUMANITIES OF CHEMISTRY}

Collateral Readings in Inorganic Chemistry

Second Series. Edited by L. A. Goldblatt. Pp. viii + 198. (New York and London: D. AppletonCentury Co., Ine., 1942.) n.p.

T a rapidly changing world the whole system of 1 education must come under review and the teaching of science cannot escape. The ideal surely is a cultural background as full as possible and a training which produces a graduate able to think both critically and constructively, with a wide know. ledge of his subject. A student who has devoted his energies mainly to the memorizing of facts, largely for the purpose of passing examinations, and is in truth little more than an encyclopædia bound in skin with all the inaccuracies of such treatises, is likely to disappoint both himself and his employers when he goes out into the world.

The problem is how to teach the mass of facts which constitute a science and at the same time show the student that the subject is real and human, even exciting when viewed from a little distance, far enough to forget the menace of an examination. Fifty years ago, when there was less to master, there was much more time for original reading. Most of us then read all we could lay our hands on, both the current journals and the classic papers of the past. They were longer but far more colourful, especially when polemic. We read about subjects remote from our own particular researches, and the chemical world was made real to us, a pleasure not a task.

This is admittedly impossible to-day, the literature is so large; moreover, the need for condensation makes most papers unreadable except by experts in the particular field. How is the student to gain an idea of the broader implications and humanities of his subject?

One answer is provided by the "Collateral Readings" edited by Mr. Goldblatt. He has reprinted and collected under one cover some thirty-six articles in inorganic chemistry by many of the leaders in the United States each of which is essentially stimulating, even exciting, and can be classed as leisure reading and not work. The first article is Bogert's "From the Cradle to the Grave", one of the best expositions of what applied chemistry is doing and can do ever written ; the others cover specific industrial subjects such as bromine or magnesium from the sea, argon, radium, phosphorus, sulphur; more theoretical subjects such as atomic weights, the periodic system, electrolytes, the polar molecule concept; or general questions like text-books and abstracts. The whole volume has a definite commercial flavour, for American chemists expect to enter industry and make their contribution to the world's progress in industrial research laboratories. They are unaware that this is still regarded in England as not quite the thing.

Taken as a whole, the articles are well selected and make first-class reading: there can be few chemists in Great Britain who would not gain from reading them. Any student who really intends his chemical studies to be serious would be bound to benefit from them and should find them far more exciting than any crime novel, of which there are so surprisingly many on both sides of the Atlantic.

E. F. Armstrong.

\section{A NEW SOCIAL SURVEY}

Nutrition and Size of Family

Report on a New Housing Estate, 1939. Prepared for the Birmingham Social Survey Committee by M. S. Soutar, Dr. E. H. Wilkins and Dr. P. Sargant Florence. Pp. 50. (London: George Allen and Unwin, Ltd., 1942.) 2s. 6d. net.

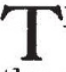

HE social, economic and environmental changes produced by the War have not so far invalidated the major findings of pre-war social surveys. The social statisties made available by the investigations at York, Bristol, Merseyside, Tyneside and other inquiries will be of value to those concerned with reconstruction. To the existing corpus of knowledge we now have to add an excellent little report prepared by the Birmingham Social Survey Committee. This report breaks new ground. Not only did the Survey set out to ascertain the extent of poverty in families of different sizes (only families with children were studied), but also it attempted to find out the adequacy of income as measured by the amount of housekeeping money in the hands of the housewife. The adoption of this realistic approach showed a startling increase of poverty with increasing family size. Thus the proportion in each group below sufficiency were: with one child 13 per cent, with two children 45 per cent, with three 65 per cent, with four 85 per cent, with five 96 per cent and with six or more 96 per cent. This method revealed that actual poverty is much greater than is disclosed by the type of measurement hitherto adopted in social survey work.

This study, which relates to a new housing estate outside Birmingham, was carried out in mid-1939 - a period of relative prosperity. In addition to its many mteresting findings, the Survey shows that bread consumption rose after rehousing. Town planners should note that, as an independent social reform, rehousing has its limitations. 